\title{
Illiberal Means for Liberal Ends: Low-Road Challenge to Public Discourse and International Relations
}

An influential strain of liberal thought demonizes certain groups and viewpoints as enemies of liberty, and supports restrictions on individual rights to further liberal ends. The use of illiberal and authoritarian means for ostensibly liberal ends, what Michael Doyle terms 'low road' liberalism, is embraced by self-described rights proponents in both the political right and left, and among key democratic states in Europe, North America and East Asia. Lowroad ideology justifies, and habituates the public to, an ever-expanding set of illiberal practices that undermine open, rational public discourse. Our essay shall analyze low-road politics and practices in various contexts (especially in US and South Korea) and how they can be countered. We focus on two, transnational human rights campaigns: the mostly rightliberal (rightist), US-led campaign against North Korea, and the left-liberal, South Korean-led campaign against Japan.

\section{Introduction}

This article analyzes a problematic strain of the liberal tradition: the embrace of non-liberal means for ostensibly liberal ends, what Michael Doyle terms 'low road' liberalism. ${ }^{1}$ Liberal theorists classically argue for respecting citizens' negative liberties (freedom from arbitrary power and interference from others) and nurturing their positive liberties (capacity and opportunity for freedom). ${ }^{2}$ A key subset of liberties includes the tolerance (negative liberty) and capacity (positive liberty) for citizens to openly and rationally discuss public issues and to influence public policy.

Liberal rights proponents generally favor liberal means (i.e., institutions and practices) to further individual rights (Doyle's 'high road' liberalism). However, an influential strain of liberals, on the political right and left, frames certain groups as enemies of freedom and not deserving of equal rights. They endorse illiberal measures against allegedly illiberal enemies, foreign and domestic, as necessary means to protect and promote liberty. The US-led campaign against Soviet-style communism (1919-91) included covert espionage against Marxist-oriented regimes (including elected Chilean President Salvador Allende), and overt and covert measures against suspected, domestic communists.

In post-Soviet era, liberals continue to 'crusade' against particular groups, although they diverge on the targets. Right-wing liberals (right-liberals or 'rightists') target groups that challenge their country's traditional mores, laws and/or security, such as Islamists at home or communist regimes abroad. Conversely, left-liberals ('leftists') target historically dominant groups that violate (or have violated) historically weak groups.

These 'low-road' measures limit the rights of individuals in the target group, even if they potentially further liberal ends, such as regime change (North Korea) or prevention of fascism (Europe). All state policies, especially low-road ones, should be subject to open, rational public debate. The most problematic low-road policies and practices-and the focus of our essay - are those that restrict public discourse itself.

Our paper shall develop the theoretical framework for low-road policies and practices, and for how they are countered. We illustrate our claims with two, competing transnational human rights campaigns: the anticommunist right, United States-led campaign

\footnotetext{
${ }^{1}$ Michael W. Doyle, 'Kant, Liberal Legacies, and Foreign Affairs', Philosophy and Public Affairs 12:3, (1983, pp. 208 (note 4).

${ }^{2}$ Doyle, 'Kant, Liberal Legacies, and Foreign Affairs', pp. 205-235.
} 
against North Korea (NK / DPRK), and the anticolonial left, South Korea-led campaign against Japan.

\section{Liberalism's High and Low Roads}

A liberal system refers to a set of institutions and practices animated by the principle that every individual possesses inalienable rights. Liberal theorists (e.g., Berlin, Doyle) distinguish between two conceptions of rights: 1) negative, i.e., freedom from arbitrary power and interference from others; and 2) positive, i.e., the capacity and opportunity for freedom. At the domestic, state-polity level, liberal principles underlie 'popular-constitutional government; a diverse society with a wide range of individual opportunities and choices; a predominantly market economy; and a substantial, strongly protected sphere of privacy and individual rights'. ${ }^{3}$ At the international level, liberal principles support rules-based relations among states, to further open trade and exchange, security cooperation, socioeconomic development, and human rights.

Two sets of liberal norms and practices support open, rational public discourse. One is a 'self-restraining tolerance', associated with negative liberty, including the willingness to listen to 'strange and even obnoxious' ideas. ${ }^{4}$ The second, associated with positive liberty, is the capacity for citizens to rationally discuss public issues and to influence political actors. This includes '[setting] forth one's own views intelligibly and candidly as the basis of a politics of persuasion rather than manipulation or coercion'. ${ }^{5}$ In a pluralist society, John Rawls would add, persuasive discourse on fundamental questions of justice and right should appeal to the common or 'public reason' of diverse citizens. ${ }^{6}$ Self-restraining tolerance and rational capacity support candid, rational public discourse, which in turn holds political actors publicly accountable for their conduct. Mark Bovens defines accountability as 'a relationship between an actor and a forum, in which the actor has an obligation to explain and justify his or her conduct, the forum can pose questions and pass judgment, and the actor may face consequences'?

Liberal rights proponents generally favor liberal means (i.e., institutions and practices), including tolerant and rational public discourse, to further individual rights (Doyle's 'high road' liberalism). However, an influential strain of liberals ('low road') frames certain groups and practices as illiberal enemies of freedom. In their righteous anger (what Doyle terms 'vehemence'), these liberals endorse illiberal measures as necessary, temporary means to counter them. For instance, affirmative, racial preference policies may temporarily violate white persons' rights, both negative (equality under law) and positive (equal opportunity), but they correct the legacy of systemic racism and ensure long-term, equal opportunity for all citizens. Protesters' destruction of property violates the rights of (mostly white) property owners, but dramatizes and challenges the injustices of a capitalist, racist society. ${ }^{8}$ International sanctions harm citizens of the targeted state, but pressure the regime to stop its illiberal behaviors and rights violations.

\footnotetext{
${ }^{3}$ William Galston, 'Liberal Virtues', American Political Science Review 82: 4, 1988, p. 1281

${ }^{4}$ Galston, 'Liberal Virtues', p. 1281.

${ }^{5}$ Galston, 'Liberal Virtues', p. 1281.

${ }^{6}$ John Rawls, 'The Idea of Public Reason Revisited', The University of Chicago Law Review 64:3, 1997, pp. 765-807.

${ }^{7}$ Mark Bovens, 'Analysing and assessing accountability: a conceptual framework', European Law Journal 13: 4, 2007, p. 450.

${ }^{8}$ Nathan J. Robinson, 'Why Damaging Property Isn't The Same As 'Violence', Current Affairs, 1 June 2020.
} 


\section{Anti-Deliberative Practices: Selective, False, and Censored Discourses}

All state policies, especially low-road ones, should be subject to open, rational public debate. However, low-road policies are often justified by Manichean, dualistic (good/evil) frames, promoted by transnational networks of rights crusaders and activists, which dismiss or censor arguments associated with despised outgroups. Specifically, low-road crusaders adopt three practices that limit open, rational discourse.

The most common is to selectively highlight some factual cases and to ignore others. Many leftist media highlight the worst cases of white police officers killing blacks, and downplay cases of police killing whites or of civilians killing police officers. Conversely, some rightist media highlight police officers injured or killed by rioters. By selectively highlighting certain words and actions, activists associate the entire outgroup with truly abusive groups of the past ('guilt by association'); they mine an Oakshottian 'practical past' of historical crimes for hyperbolic analogies with the present. ${ }^{9}$ Many left-liberals linked contemporary Trump supporters and cultural conservatives (e.g., United Daughters of the Confederacy) in US to early twentieth century Ku Klux Klan (white supremacists), and European nationalist parties (e.g., AfD) to the 1930s German fascists. Conversely, rightist commentators seized on various cases of leftist censorship to compare the 'Black Lives Matter' campaign to the Chinese Cultural Revolution. ${ }^{10}$

Less common is to intentionally disseminate flawed or false information. In the aftermath of 2001 (9/11) terrorist attacks, Ahmed Chalabi's Iraqi National Congress allegedly provided US intelligence false information about Iraqi President Saddam Hussein's ties to alQaeda and weapons of mass destruction. The Bush administration accepted such flawed information and ignored contrary evidence of European allies (e.g., France, Germany).

Also less common, but most limiting, is to censor and punish oppositional discourse, on the grounds that they harm victimized groups. In a US survey, 72 percent of university students supported disciplinary action against 'any student or faculty member on campus who uses language that is considered racist, sexist, homophobic or otherwise offensive'. ${ }^{11}$ In 2020, universities ostracized students and professors who criticized the 'Black Lives Matter' campaign against police brutality. ${ }^{12}$ Portland State Professor Bruce Gilley's 'Viewpoint' article defending colonialism was officially withdrawn after Third World Quarterly journal's editor received death threats, and Gilley was investigated by the university's diversity office for alleged discrimination and harassment. ${ }^{13}$ Legal theorist Jeremy Waldron argues for criminally banning 'hate' speech against minority groups as group libel ${ }^{14}$, and his thesis has been cited to support Germany's de jure ban against pro-Nazi speech (even jokes) and South Korea's de facto ban against criticizing former comfort women. ${ }^{15}$

\footnotetext{
${ }^{9}$ Michael Oakeshott, On History and Other Essays (Oxford: Basil Blackwell, 1983).

${ }^{10}$ David Harsanyi, Welcome to America's Cultural Revolution', National Review, 9 June 2020.

${ }^{11}$ Erwin Chemerinsky and Howard Gillman, Free Speech on Campus (Yale University Press, 2017), 9.

${ }^{12}$ Nick Bromberg, 'Marquette revokes scholarship offer to lacrosse player after she compares Floyd's death to Kaepernick's protest', Yahoo Sports, 3 June 2020; Michael Levenson, 'University to Investigate Professor Who Tweeted About 'Black Privilege', New York Times, 5 June 2020.

${ }^{13}$ Vimal Patel, 'Last Fall This Scholar Defended Colonialism. Now He's Defending Himself', Chronicle of Education, 21 March 2018.

${ }^{14}$ Jeremy Waldron, 'Dignity and Defamation: The Visibility of Hate', Harvard Law Review 123: 7, 2010, pp. 1596-1657.

${ }^{15}$ Maeda Akira, 'The South Korean Controversy Over the Comfort Women, Justice and Academic Freedom: The Case of Park Yuha', The Asia Pacific Journal (Japan Focus) 14: 4-2, 15 February 2016, https://apijf.org/2016/04/Maeda.html.
} 
Typically, the politically dominant faction in any society narrates what group or viewpoint is harmful, and thus deserves to be restricted. In Western Europe, left-liberals narrate that Holocaust denialists are harmful, but not newspaper cartoonists satirizing Prophet Muhammad. In US, rightist-liberals narrate that we should sanction Iran for human rights violations, but not Saudi Arabia. Without constraints, the dominant faction can routinely curtail the rights of particular outgroups, domestic or foreign, and habituate the public to an ever-expanding set of anti-deliberative practices that limit public discourse.

Load-road, anti-deliberative politics face two checks in most, major (e.g., OECD) democracies: 1) competing, low-road factions and 2) high-road liberals. Firstly, the low-road polices of one faction often fuel competing factions. Leftist support for minority racial preferences and/or speech restrictions animates opposing, white nationalist groups (USA) and populist-nationalist parties (Europe). The leftist campaign to retract Professor Gilley's article, for instance, stoked rightist, online harassment of his critics. ${ }^{16}$ Competing, anti-deliberative practices (e.g., academic censorship, online harassment) between low-road factions do not generate a virtuous, political discourse 'of persuasion rather than manipulation or coercion' (Galston); but they limit any one faction from monopolizing the public discourse. Competing, low-road factions potentially maintain a balance of power, creating open space from which high-road discourse can operate and expand.

The second check is a still-vibrant strain of high-road, liberal discourse from the political left, center, and right, which oppose illiberal practices, especially censorship, whatever the source. Left-liberal Noam Chomsky publicly defended both Bruce Gilley from low-road left, and University of South Florida Professor Sami Amin Al-Arian from low-road right. ${ }^{17}$ Highroad liberals, across the political spectrum, play the role of honest, credible referees among competing, low road factions, subject non-liberal policies to rational, public deliberation, and criticize illiberal practices that restrict such deliberation.

Our paper shall develop these claims with two transnational, human rights campaigns: the anticommunist right, US-led campaign against North Korea (NK), and the anticolonial left, South Korea-led campaign against Japan. As defined in our paper, low-road liberals ('lowliberals') engage in, or publicly support those who engage in, anti-deliberative practices, notably disseminating false information and censoring oppositional discourse. High-liberals publicly oppose anti-deliberative practices, whatever their source.

\section{Anticommunist right campaign against North Korea (NK)}

On 1 Sept. 2017, the Trump administration enacted a 'Geographical Travel Restriction' that prevented Americans, including humanitarian workers, from travelling to or through the Democratic People's Republic of Korea (DPRK). The travel ban was announced after the 19 June 2017 death of Otto Warmbier, an American university student arrested in North Korea for stealing a government poster and whose imprisonment left him in a vegetative state. The travel ban was one of many US-led sanctions against North Korea, for its nuclear and ballistic missiles program and human rights violations. The sanctions severely limited the positive and negative liberties linked with economic development for ordinary North Koreans. They also limited the liberty of US citizens, including faith-based organization (FBO) workers, to travel to and work in North Korea.

\footnotetext{
${ }^{16}$ Anya Kamenetz, 'Professors Are Targets In Online Culture Wars; Some Fight', NPR, 4 April 2018.

${ }^{17}$ Patel, 'This Scholar Defended Colonialism'; National Coalition to Protect Civil Freedoms, 'A

Message by Dr. Sami A. Al-Arian to His Friends and Supporters (5/1/2006)', http://www.civilfreedoms.org/?p=4562.
} 
The Trump Administration's sanctions campaign was justified by a Manichean frame, promoted by transnational networks of human rights crusaders, which portrayed the DPRK as a totalitarian state that oppressed its people and especially Christian believers, and that therefore cannot be trusted with nuclear weapons. The anti-NK campaign exemplified an anticommunist frame that highlighted (and sometimes exaggerated) the human rights violations of Marxist-oriented regimes (e.g., Cuba, Venezuela, China). Anticommunist rightists seized on these alleged rights violations to punish communist regimes abroad, and their leftist collaborators at home, a strategy that Clifford Bob terms the 'weaponization of rights' ${ }^{18}$

The anti-DPRK campaign was centered in US, South Korea, Japan, and western Europe. Particularly influential were evangelical Christian organizations (e.g., Open Doors, Voice of the Martyrs), which advocated for persecuted Christians against oppressive regimes, of which North Korea was the worst. During the 2018 Pyeongchang Olympics, Open Doors declared: 'Let us not forget that every day over 300,000 Christians [in North Korea] are denied the right to take part in the religious observance of their choice. They are a beleaguered community who are fighting for their very survival'. ${ }^{19}$

Rightist, evangelical organizations also furnished the underground networks that helped North Koreans escape ('defect'), and most defectors converted to evangelical Christianity after settling in South Korea. ${ }^{20}$ Most defector-activists were both religiously evangelicals and politically affiliated with anticommunist rightist parties: Ji Seong-ho ${ }^{21}$, the disabled defector celebrated in Trump's 2018 State of Union address, was an elected legislator from South Korea's major rightist United Future Party. Their testimonies were widely cited in US rightist (e.g., Daily Caller, Fox News) and evangelical (e.g., Christian Post) media, and by evangelical politicians (e.g., Vice President Mike Pence, Secretary of State Mike Pompeo).

\section{Selective, False, and Censored Information}

The anti-NK campaign relied heavily on the testimonies of NK refugees ('defectors'), who allegedly experienced the regime's abuses. Anti-NK campaigners publicized the survivors' testimonies, which selectively highlighted the worst rights violations. Some also disseminated testimonies that turned out to be exaggerated or false.

In 2002, defector and self-identified Christian, Lee Soon-ok, testified to the US Senate that in a political prison, security officers killed Christian inmates 'by pouring molten iron on them one by one'. ${ }^{22}$ Lee was later found not to be a political prisoner but 'a petty economic criminal'. ${ }^{23}$ In a best-selling memoir Escape from Camp 14 (2002), Shin Dong-hyuk wrote that he grew up in Camp 14 (the most isolated prison) and was tortured by guards at age thirteen. Shin later admitted that he spent much of his childhood in the less-notorious Camp

\footnotetext{
${ }^{18}$ Clifford Bob, Rights as Weapons: Instruments of Conflict, Tools of Power (Princeton: Princeton University Press, 2019).

${ }^{19}$ Samuel Smith, 'Don't Be Fooled by Korean Unity at Winter Olympics, Open Doors Warns', The Christian Post, 11 February 2018.

${ }^{20}$ Jung Jin-Heon, Migration and Religion in East Asia: North Korean Migrants' Evangelical Encounters (London: Palgrave Macmillan, 2015).

${ }^{21}$ Koreans conventionally list surname (Ji) first and then given name (Seong-ho).

22 'Testimony of Ms. Soon Ok Lee', US Senate, 21 June 2002, https://www.judiciary.senate.gov/imo/media/doc/lee testimony $0621102 . p d f$.

${ }^{23}$ Jiyoung Song, 'Unreliable Witnesses: The Challenge of Separating Truth from Fiction When It Comes to North Korea', Policy Forum, 2 Aug 2015.
} 
18 and that he was tortured at age twenty (not thirteen). ${ }^{24}$ In 2014, Park Yeon-mi testified that in her former hometown, her friend's mother was publicly executed for watching a Hollywood movie, a claim that was refuted by other defectors from the region. In 2014, Ji Seong-ho claimed, citing other defectors, that the Kim Jong-un regime was systematically purging and torturing its disabled population, such as castrating male dwarfs 'so they would become extinct' (The Telegraph, 11 Dec. 2014).

Many anti-NK crusaders excused these testimonies to be 'small factual errors' that do not challenge the 'big picture'. Said defector-activist Choi Sung Chol (UK One Korea Association): 'Most North Koreans do not worry about small factual mistakes as long as the big picture that North Korea violates human rights is right. We, North Koreans, know what is true and what is fake, but, at the same time, we do not want to ruin the bigger political moves like the UN COI [Commission of Inquiry] or the US human rights act' ${ }^{25}$

Finally, in US (until mid-1950s) and South Korea (until mid-1990s), the dominant political parties were anticommunists and criminalized 'pro-communist' discourses. In US, the Communist Control Act (1954) criminalized membership in, or support for the US Communist Party or "Communist-action" organizations, although federal courts later ruled it unconstitutional. In South Korea, the National Security Act (1948) criminalized the distribution of information from or supporting North Korea. (Even after 1990s transition to civilian-led democracy, South Korea remained the only country to ban official DPRK newspapers and websites.) From 1948 to 1997, South Korean ruling parties systematically disseminated 'misinformation and inaccurate information' ${ }^{26}$ about North Korea, andthrough the National Security Act - vigorously punished dissenters who challenged such propaganda. As recently as 2015, the rightist Park Geun-hye administration deported KoreanAmerican Shin Eun-mi for five years, for favorably speaking about her visits to North Korea.

\section{Oppositional Discourses: Low-left and high-liberals}

Most US left-liberals (i.e., Democratic Party) historically did not oppose anticommunist campaigns, and currently do not oppose the sanctions campaign against North Korea. But a small faction of 'anticolonial' leftists in USA, and a large faction in South Korea, denounce the sanctions as part of a longstanding, imperial domination of the Korean peninsula. Minju Bae and Ju-Hyun Park (New York-based Nodutdol for Korean Community Development) wrote:

Since [1948], the U.S. has done everything in its power to destroy the DPRK, from carpet bombing more than 90 percent of the country from 1950-1953, to modern-day bipartisan economic sanctions, which deprive North Koreans of life-saving necessities...As part of its decades-long war against North Korea, the U.S. aided and abetted South Korean dictators Rhee Syngman, Park Chung-hee and Chun Doo-hwan in brutally crushing reunification and democratization movements....The U.S. and South Korean militaries also collaborated in creating systems of institutionalized sexual assault of Korean and migrant women, including medical torture and forced sterilization of sex workers who serviced U.S. military personnel. Decades of

\footnotetext{
${ }^{24}$ Helen Nianias, 'Shin Dong-hyuk: What You Need to Know about the North Korean Prisoner who Admitted Claims in Bestseller Escape From Camp 14 were False', The Independent, 19 Jan 2015.

${ }^{25}$ Song, 'Unreliable Witnesses'.

${ }^{26}$ Richard Kagan, Matthew Oh, and Davis Weissbrodt, Human Rights in the Democratic People's Republic of Korea (Washington DC: Minnesota Lawyers International and Asia Watch, 1988).
} 
worker, student and rural organizing eventually made South Korea a democracy in the 1990s, but the U.S. military occupation continues. ${ }^{27}$

Anticolonial leftists disseminated their own share of false rumors, lacking empirical evidence, such as US or South Korean militaries forcibly sterilizing sex workers.

Leftist organizations (Korea Peace Now, Alliance of Scholars Concerned about Korea) in USA, and much of the leftist media and parties in South Korea, vigorously challenged the anti-NK campaign and the testimonies of defector-activists. ${ }^{28}$ They also partnered with relatively nonpartisan, high-liberals, such as humanitarian FBO workers, who offered broadly credible information about North Korea. ${ }^{29}$ The testimonies of FBO workers resonated among both US mainstream and evangelical media and key government officials, and some humanitarian FBOs successfully applied for travel ban exemptions. Another credible group were nonpartisan academics and journalists (e.g., Andrei Lankov, Jiyeon Song,), who investigated the claims of defector-activists. For its well-publicized, 2019 report on ordinary North Koreans harmed by sanctions, the leftist Korea Peace Now featured a prominent social scientist (Henri Féron, Ph.D., Senior Fellow at the Center for International Policy), medical doctor (Kee B. Park, MD, MPH, Director of the DPRK Program at the Korean American Medical Association), and faith-based worker (Joy Yoon, Co-founder of Ignis Community and Pyongyang Spine Rehabilitation Center). ${ }^{30}$

In the US, the coalition of low-left and high-liberals created space for mainstream Democrats, such as US House Representative Ro Khanna, to call for lifting some sanctions and formally ending the Korean War. ${ }^{31}$ Still, they remained a marginal voice in US politics and media. The DPRK was consistently the least-liked country among Americans ${ }^{32}$ and regularly portrayed as villains in Hollywood movies, for instance, Die Another Day (2002), Olympus Has Fallen (2013), and The Interview (2014).

In South Korea, the leftist faction - represented by Democratic Party of Korea (DPK) has, since 2017, dominated politics and popular media. The DPK-led government has rarely punished anybody for publicly supporting communism or for praising DPRK leader Kim Jong-un. ${ }^{33}$ President Moon Jae-in personally embraced Kim Jong-un, and South Korean television dramas portrayed DPRK army officers as sympathetic, even romantic figures, for instance, Crash Landing on You (2019).

Since 2017, Seoul has consistently lobbied Trump to lift sanctions and normalize ties with North Korea. Ironically, even as the anticolonial left in South Korea humanized North Korea regime and lifted restrictions on 'pro-North Korea' discourse, it actively demonized Japan and restricted 'pro-Japan' discourse, as discussed below.

\footnotetext{
${ }^{27}$ Minju Bae and Ju-Hyun Park, 'Democrats Must Stop Dismissing Diplomacy With North Korea', Truthout, 18 September 2019.

${ }^{28}$ Park Han-sik, 'The fallacy of regime change in N. Korea and distorted perceptions of defectors among S. Koreans and Americans', Hankyoreh, 14 April 2020.

${ }^{29}$ Joseph Yi and Joe Phillips, 'Christian Case for Engaging North Korea,' Pacific Affairs 91:3, Sept. 2018, pp. 523-537.

30 'First Comprehensive Assessment of the Impact of Sanctions Against North Korea Shows Adverse Consequences for Civilians, Especially Women', Korea Peace Now, 30 October 2019.

${ }^{31}$ Reps. Ro Khanna, Barbara Lee and Andy Kim introduce resolution calling for formal end to Korean War, Press Release, 26 Feb. 2019. https://khanna.house.gov/media/press-releases/release-reps-rokhanna-barbara-lee-and-andy-kim-introduces-resolution-calling

${ }^{32}$ Megan Brenan, 'Americans Like Canada Most, North Korea Least, Gallup,' 28 February 2018.

${ }^{33}$ Nicola Smith and Junho Lee, 'South Korea's Kim Jong-un Fan Clubs Prepare Welcome as North Korean Leader Vows Visit to Seoul', The Telegraph, 30 Dec 2018.
} 


\section{Anticolonial left campaign against Japan}

On 30 October 2018, the Supreme Court of South Korea ruled that Japanese steelmaker Nippon Steel \& Sumitomo Metal Corp should compensate four colonial-era, conscripted laborers 100 million won each $(\$ 87,680)$. According to Seoul, Imperial Japan conscripted 480,636 Korean laborers during the final years of its occupation (1910-45). That decision allowed victims of forced labor or their surviving families to seize assets of the modern successors of colonial-era Japanese companies (e.g., Mitsubishi Heavy Industries). Tokyo rejected the decision, arguing that the bilateral, 1965 Treaty on Basic Relations, which provided Seoul $\$ 300$ million in grants (\$2.4 billion in 2019) and \$200 million in low-interest loans, 'settled completely and finally' all property claims between the 'Contracting Parties and their nationals' related to Japan's occupation. ${ }^{34}$

South Korean President Moon Jae-in rebuffed Tokyo's proposal for diplomatic consultation or third-party arbitration, as stipulated by 1965 treaty. Tokyo responded by, first, tightening regulations for exporting three materials essential to the Korean semiconductor industry (1 July 2019) and then removing South Korea from its 'white list' of trusted countries for trade in sensitive materials (1 August 2019). Seoul retaliated by removing Japan from its own white list, and the ruling DPK party encouraged a boycott of products from, and tourism to, Japan.

The 2018 Court decision was endorsed by President Moon, who appointed eight of the 13 presiding Justices. It was the latest, government-supported measure against presentday Japanese entities, Korean descendants of colonial collaborators, and modern-day apologists. These include expropriating property worth over $\$ 100$ million from families of collaborators (2005 Special law to redeem pro-Japanese collaborators' property); erecting comfort women statutes in front of the Japanese embassy (Seoul) and consulate (Busan), in contravention of the 1961 and 1963 Vienna Conventions; and fining or imprisoning academics whose statements dissent from the anti-Japan narrative.

The punitive measures were justified by a Manichean narrative, which characterized the postwar Japanese government as unrepentant denialists of colonial-era crimes. Since the founding President Rhee Syngman (1948-60), who styled himself as both anti-Japanese and anticommunist, the South Korean state has characterized Imperial Japan's colonization of Korea as exceptionally oppressive. President Park Chung-hee (1961-79) maintained the antiJapan narrative, but negotiated the 1965 Basic Relations Treaty to normalize ties with Tokyo and accelerate economic development.

All significant political parties in South Korea identify as nationalists, who defend the Korean nation against external enemies. The political left-right divide is centered on the alleged enemies. For the anticommunist right, which dominated South Korean politics from 1947 to 1997 and which is currently represented by major opposition United Future Party, the primary enemies are communists who enslaved the northern half of the nation (North Korea), and their leftist collaborators in South Korea. For anticolonial left, represented by the ruling Democratic Party of Korea, the real enemies are the colonial-era Japanese, who enslaved the whole nation, and their rightist collaborators in South Korea. ${ }^{35}$

\footnotetext{
34 'Agreement between Japan and the Republic of Korea Concerning the Settlement of Problems in Regard to Property and Claims and Economic Cooperation' (1965). United Nations, Treaty Series. https://treaties.un.org/doc/Publication/UNTS/Volume\%20583/volume-583-I-8473-English.pdf.

${ }^{35}$ Gi-Wook Shin, Ethnic Nationalism in Korea: Genealogy, Politics, and Legacy (Stanford: Stanford University Press, 2006); Joseph Yi, Joe Phillips and Wondong Lee, 'Manufacturing Contempt: Statelinked Populism in South Korea,' Society 56:5, 2019, pp. 494-501.
} 
South Korean leftists characterized the 1965 treaty as a betrayal by pro-Japanese collaborators and sought to revise or reinterpret the language to address Japan's 'crimes against humanity'. In the 1990s, as Korea transitioned from right-wing authoritarianism to multiparty democracy, some organizations, notably the Korean Council for Justice and Remembrance for the Issues of Military Sexual Slavery by Japan (in short, Korean Council) added the striking claim that the Japanese military forcibly abducted 200,000 Korean women and girls to be sex slaves ('comfort women'). Leftist politicians argued that, unlike postwar Germany, postwar Japan has denied or distorted its past. In August 2019, President Moon declared:

[Japan's] attitude toward historical issues has been never honest...It is an immutable fact that Japan was the perpetrator behind unfortunate chapters of history not only in Korea but also in many other Asian countries. The attitude of the Japanese Government, which neither acknowledges nor repents its past wrongdoings but rather distorts history, only aggravates the wounds and anguish of the victims. ${ }^{36}$

Since the 1990s, leftist crusaders mobilized a domestic and international campaign to pressure the Japanese state to sincerely apologize to and compensate the victims. Mainstream and popular South Korean media graphically described Koreans' suffering during colonial rule. Nearly every year since 1995 , filmmakers released popular movies about comfort women. ${ }^{37}$ In Spirits' Homecoming (2016), Japanese soldiers kidnap, abuse, and kill Korean girls, burning their bodies to destroy evidence. Homecoming, widely praised in Korea, received the country's 21 st Chunsa Film Art Award.

Since 2010, the anti-Japan campaign has expanded overseas, including placing photos of alleged forced laborers on a Times Square billboard; replicating comfort women statues in Canada, the United States, Australia, and Germany; and supplementing the high school curriculum in California with textbooks equating the comfort women system with the Holocaust, American slavery, and the Armenian genocide. ${ }^{38}$ Ethnic Korean students in North America have equated Japan's 'Rising Sun' flag with the Nazi swastika and demanded its removal from public schools. ${ }^{39}$ Comfort women advocates have persuaded the European Parliament (2007), U.N. Committee on the Elimination of Racial Discrimination (2014), and United States House of Representatives (2017), among other bodies, to call on Japan to redress the situation.

The anti-Japan campaign has persuaded most South Koreans that Japan and its elected leaders are not to be trusted. In 2018, South Koreans rated Japan (3.55 on a 10-point scale) and Prime Minister Shinzo Abe (2.04) lower than North Korea (4.71) and Kim Jong-un

\footnotetext{
36 'Opening Remarks by President Moon Jae-in at Cabinet Meeting on Japan's Removal of Korea from Its Whitelist of Trusted Trading Partners', Korea.net, 29 August 2019..

${ }^{37}$ S-H Yoo, 'Herstory' Opens New Chapter in Painful Tale of Comfort Women Victims', Hankyoreh, 11 June 2018; M-S Yoon, "My Name Is Kim Bok-dong' Tells Tale of Comfort Women, Champion of Human rights', Korea Herald, 25 July 2019.

${ }^{38}$ Agnes Constante, 'New Teacher's Guide on 'Comfort Women' to be Distributed across California Schools', NBC News, 16 Jan 2019; Curriculum and Resources for 'Comfort Women' Education, https://comfortwomeneducation.org, 9 April 2019.

${ }^{39}$ Min-ho Jung, 'Korean Students up in Arms over 'Rising Sun' Flag in Canadian Classroom', Korea Times, 19 Nov 2018.
} 
(4.06). ${ }^{40}$ South Korea is the only electoral democracy in the world whose citizens trust North Korea more than Japan.

In 2015, Japanese Minister Shinzo Abe reached an accord with rightist Korean President Park Geun-hye to provide a general apology and compensation (1 billion yen or approx. $\$ 9.27$ million) to former Korean comfort women, which 35 out of 46 comfort women survivors and 68 relatives of deceased comfort women accepted. Tokyo maintained its stance of no evidence that its military ordered any abduction of Korean women. Korean media criticized Japan's denial of criminal legal responsibility, for instance, 'Despite a much-touted deal with Seoul and an apology to the 'comfort women', Tokyo was found Sunday to have once again denied the forcible nature of its mobilization of sex slaves' (Korea Times, 31 Jan. 2016). After his 2017 election, President Moon effectively terminated the 2015 accord.

The anti-Japan campaign fit within an anticolonial frame that highlighted (and sometimes exaggerated) the human rights violations of imperial regimes (e.g., UK, US, France, Germany) in colonial societies (e.g., India, Philippines, Algeria, Namibia). Postindependence leftists seized on these alleged violations to demand redress from formerly imperial states abroad and punish collaborationist-supporters at home. Some leftist writers in western countries ${ }^{41}$, and nearly all in South Korea, linked human rights violations during colonial era to that of German Nazi regime. Korea Times editor Oh Young-jin argued that 'by no means would the suffering of the comfort women be less painful than that of those killed en masse in the Nazi gas chambers' and that western countries need to 'see Korea's misery as compelling as they see the Jewish Holocaust' (Korea Times, 2 June 2017).

\section{Selective, False, and Censored Information}

Mirroring the anti-DPRK rightist campaign, the anti-Japan leftist campaign relied on the testimonies of those who allegedly experienced human rights violations. The leftist campaign selectively highlighted the worst violations and omitted information that did not fit the antiJapan narrative. For instance, Kim Hak-sun was the first to come out publicly as a former comfort woman in South Korea and was the model for the famous comfort woman statue in San Francisco. In Kim's original testimonial (given to Yun Chong-ok, the founding corepresentative of the Korean Council), she claimed that her foster father took her and another girl to China, and that he worked as the manager of the local comfort station. In the 1993 published testimony, the Korean Council omitted mention of her foster father. ${ }^{42}$

The Korean Council also publicized information that it likely knew to be problematic. Notably, former comfort woman Lee (Yi) Yong-Soo was the icon of the antiJapan campaign and President Moon's guest of honor during US President Trump's first official visit to South Korea (7 Nov. 2017). In her original, written testimony (1992), Lee testified that, at age 16, she and her friend together escaped from her Daegu home and ended up at a privately-run comfort station in Taiwan; the brothel owner inflicted physical violence, including electric shocks; and Lee stayed for less than a year in Taiwan. ${ }^{43}$ As Lee actively participated in the redress campaign, her public testimonies shifted. In 2007, Lee publicly testified that she was forcibly dragged out of her home in the middle of the night by Japanese

\footnotetext{
40 'South Koreans' Perceptions of Neighboring Countries', Asan Institute for Policy Studies, 6 July 2018.

${ }^{41}$ For instance, Aimé Césaire, Discourse on colonialism (New York: Monthly Review Press, 1955); Frantz Fanon, The wretched of the earth (New York: Grove Press, 1961).

${ }^{42}$ Sarah C. Soh, The Comfort Women: Sexual Violence and Postcolonial Memory in Korea and Japan (University of Chicago Press, 2008), pp. 127-128.

${ }^{43}$ Sarah, The Comfort Women, pp. 98, 100-101; also see 'Comfort Women: Testimony of Lee YongSoo, which is considered most reliable the witness,' http://warehouse9.blogspot.com.
} 
soldiers, covering her mouth so she could not call to her mother; Japanese soldiers (not the private brothel owner) inflicted physical violence and electric shocks; and she was taken at the age of fifteen (instead of sixteen) and returned home when she was nineteen, implying that she spent four years (instead of less than a year) at the comfort station.

Most South Korean media and academia ignored information dissenting from the anti-Japan narrative, such as the testimonies of former comfort women who accepted the 1995 and 2015 Japanese compensations. Park Yu-ha reports, 'The late [survivor] Bae Chunhee said she had not been taken by force, and that she wanted to forgive Japan but could not say so. ${ }^{44}$ Korean media also did not question the discrepancies among the activists' testimonies, such as Lee's. Neither did the media discuss the lack of corroborating evidence. Apart from the fabricated testimony of Seiji Yoshida, no Japanese soldier has testified to forcibly abducting women from the colonies of Korea or Taiwan. Finally, Korean media largely ignored the well-documented finding that post-1945 South Korean governments encouraged and supervised brothels for American soldiers, or the allegation that South Korean troops patronized local women in Vietnam.

Left-leaning US media also chastised Japanese Prime Minister Shinzo Abe for denying the abduction testimonies of comfort women activists. 'In making such denials, [Abe] was in effect dismissing as liars the aging women now coming forward with tearful testimony of their ordeals' (New York Times, 5 March 2007). Even as US media cautioned about offending elderly women, they did not consider how their claims may broadly defame elderly, former Japanese soldiers as kidnappers. In US and South Korea, the dominant media narrated what groups were victims and deserved to be protected (in this case, former comfort women), and what groups were not (former imperial soldiers).

Anticommunist, rightist campaigners similarly publicized selective and false information, however, since mid-1950s in US and mid-1990s in South Korea, they have not effectively blocked alternative, 'pro-communist' voices from public discourse. But in South Korea, anticolonial leftists have vigorously punished 'pro-collaborator' discourse. The few academics that openly disputed the abduction narrative have been investigated by their universities and prosecuted by the government for 'defaming' former comfort women. In South Korea, one may be both civilly or criminally liable for stating harmful truths about another; criminal liability includes up to three years imprisonment or a 20 million won $(\$ 17,000)$ fine. (A person is exonerated from defamation if these facts serve the public interest.) If one makes harmful falsehoods, then he/she is criminally liable for seven years prison or a 50 million won $(\$ 42,000)$ fine. ${ }^{45}$

In 2013, Sejong University professor, Park Yu-ha, published a book revealing the diversity of comfort women experiences and challenging the veracity of some testimonials. ${ }^{46}$ Nine comfort women activists sued Park for civil and criminal defamation, and government prosecutors requested a three-year prison sentence. A Seoul civil court partially censored Park's Korean-language book and fined her 90 million won ( $\$ 74$ thousand) for defamation. A Seoul criminal court acquitted Professor Park on defamation charges; but, on 27 October 2017, after Moon's election, a Seoul appeals court overturned Park's acquittal and fined her

\footnotetext{
${ }^{44}$ Kim Kyu-nam, 'Prosecutors seek three years in prison for professor who wrote about comfort women,' Hankyoreh, 21 Dec. 2016.

${ }^{45}$ Sean Hayes, 'Korea's Cyber Defamation Law: Basics of Libel and Slander in Korea', The Korean Law Blog, 7 Aug. 2015.

${ }^{46}$ Park Yu-ha, 제국의 위안부 Jegug-ui Wianbu [Comfort Women of the Empire] (Seoul: Puriwa Ipari, 2015).
} 
10 million won $(\$ 8,848)$. Prosecutors have appealed, again seeking a three-year jail term. ${ }^{47}$ On 26 April 2017, a Sunchon National University professor ('Song') lectured to his class that some Koreans 'probably' volunteered to be comfort women. The university terminated Song's employment, and a court sentenced him to six months in prison. ${ }^{48}$ Yonsei University professor Ryu Seok-chun described the comfort women as 'kind of prostitutes' during a September 2019 lecture. The university promptly suspended Ryu from teaching and launched an ethics inquiry. Seoul police opened a criminal investigation into whether he stated harmful falsehoods (liable for seven years imprisonment). ${ }^{49}$

Low-left crusaders (e.g., academics, media, prosecutors) focused not on whether the dissenting statements were empirically valid, but whether they harmed the victims. Editorialized Korea Times (24 September 2019): 'We Koreans enjoy freedom of speech, freedom of thought and academic freedom, but [Professor] Ryu has seemingly abused these constitutional freedoms to distort history and gloss over the brutal atrocities committed by Japan during its 1910-45 colonial rule of the Korean peninsula'.

\section{Oppositional Voices: Low-right and high-liberals}

Like the anticommunist right campaign against North Korea, the anticolonial left campaign against Japan was disputed by a mix of low- and high-road liberals. In South Korea, initially, anticommunist rightists did not challenge the leftists' anti-Japan campaign. From Rhee Syngman to Park Geun-hye administrations, traditional rightist ('old right') parties and media (e.g., Chosun Ilbo) had competed with leftists to promote ethnic (Korean) nationalism and demonize Japan. However, with US encouragement, rightist governments signed bilateral agreements with Japan, notably Park Chung-hee's 1965 Treaty on Basic Relations and Park Geun-hye's 2015 accord on comfort women. President Moon's rejection of the 2015 accord and-by supporting the Supreme Court's forced labor ruling-implicit rejection of the 1965 Treaty, plus his rapprochement with North Korea, were steps too far for traditional rightists. Rightists feared the communist regimes of North Korea and China more than Japan, and denounced Moon's shifting South Korea from US and Japan to a de facto, trilateral alliance with North Korea and China.

In this context has become prominent a 'new-right', which-in contrast to old-right-explicitly rejected anti-Japanese, ethnic nationalism ('tribalism') and asserted classically liberal values (e.g., individual freedom, rationality). Starting with online lectures (22 August 2016) and then a 2019 national best-selling book (Anti-Japan Tribalism), former SNU professor Lee Young-hoon and other scholars challenged the anticolonial narrative on comfort women, forced laborers, and other alleged rights violations; for instance, they argued, the true number of Korean comfort women were around 5000, not 200,000, and private brokers ('pimps') largely recruited through advance payments or deception, not through military force. ${ }^{50}$ The new-right's revisionist history was de facto censored in public schools and mainstream media, therefore, it disseminated in alternative, online media,

\footnotetext{
47 'South Korean Academic Convicted of Defaming 'Comfort Women', The Straits Times, 27 Oct 2017.

${ }^{48}$ T-H Lee, 'Professor Gets Prison for Insulting Comfort Women', Korea Times, 15 Nov. 2018.

${ }^{49}$ A. Chung, 'Police Probe Professor for Wartime Sex Slavery Remarks,' University World News, 9 October 2019.

${ }^{50}$ T. Nishioka, 'Why Korean Professor Believes Comfort Women Were Not Sex Slaves,' Japan Forward, 24 November 2017.
} 
including Youtube channel Jeong Kyu-jae TV (est. 13 Feb. 2012) and online newspaper PenNMike (https://www.pennmike.com; est. 6 Dec. 2017). ${ }^{51}$

Since Moon's 2017 election, pro-new right, online media attracted growing viewers, who sought alternatives to the government-influenced, mainstream media: in August 2018, they produced five of the 50 most-watched video clips on YouTube Korea. New-right media and civic organizations (e.g., Truth Forum, One Korea Network) criticized the leftist Moon administration for favoring North Korea and China, and for attacking Japan, when most Japanese and South Koreans shared liberal-democratic values. Korean new-rightists' embrace of traditional 'western' values ('markets and morality'), opposition to communist North Korea and China, and disavowal of narrow ethno-nationalism, closely aligned with the agenda of rightist parties, activists, and media in US and Japan. The latter criticized the Korean Council for opposing the 2015 comfort women agreement and for supporting North Korea. $^{52}$

Since 2017 and especially after April 2020 midterm elections, anticommunist rightists (old and new) saw themselves as a persecuted, political minority. On 3 June 2020, defector-activist Lee Ju-seong was sentenced to six months in prison for publishing 'false' allegations of a conspiracy between the late leftist President Kim Dae-jung and North Korean agents, behind the 1980 Gwangju Uprising. ${ }^{53}$ In this context, rightist media publishers, such as Taro O, stressed the constitutional right to speech.

Mr. Lee Ju-seong... and others should be able to discuss the Gwangju incident freely, without the fear of imprisonment, financial bankruptcy, and physical and psychological harm that they have been subjected to....The judiciary, legislative, and executive branches of South Korea should uphold the constitution and the ideals of the Universal Declaration of Human Rights. ${ }^{54}$

Even as new-rightists criticized the speech restrictions imposed by the leftist Moon government or the embellished testimonies of comfort women activists, they rarely criticized the egregious violations of past rightist governments (e.g., Rhee Syngman, Park Chung-hee) or the embellished testimonies of NK defector-activists. Still, the rightist opposition to the leftist government created space for nonpartisan, 'high-road' scholars, such Park Yu-ha, whose work also challenged the leftist, anti-Japan narrative. Park was supported by likeminded, principled liberals, including 190 Korean intellectuals, 54 Japanese (e.g., Nobel Laureate Kenzaburō Ōe, former Socialist Prime Minister Tomiichi Murayama), and US academics Noam Chomsky and Bruce Cumings. ${ }^{55}$ Even though Park Yu-ha was not allied

\footnotetext{
${ }^{51}$ S. Cha and J. Park, 'South Korean YouTubers Lure Japanese Audience with Attacks on Moon', Reuters, 23 July 2019.

${ }^{52}$ Norm Coleman, 'Don't let North Korea Divide U.S. Allies in Asia,' The Hill, 11 Aug 2016;

MichaelYon, Facebook, 24 Feb. 2018, https://www.facebook.com/MichaelYonFanPage/posts/alert-tous-japan-rok-and-vietnamese-intelligence-intelligenceinformation-operat/10155347208200665/.

${ }^{53}$ John Power, 'In South Korea, history and free speech collide in a battle to define democracy,' South China Morning Post, 5 June 2020.

${ }^{54}$ Taro O, 'Kim Dae-Jung Center Sues An Escapee Lee Ju-Seong for Libel for His Book on Gwangju (5.18) Uprising and North Korean Involvement; Ruling Party Plans 5.18 Gag Law', East Asia

Research Center, 28 May 2020. https://eastasiaresearch.org/2020/05/28/kim-dae-jung-center-sues-anescapee-lee-ju-seong-for-libel-for-his-book-on-gwangju-5-18-uprising-and-north-koreaninvolvement-ruling-party-plans-5-18-gag-law/

55 'Statement against the Indictment of Professor Yuha Park'. https://parkyuha.org/archives/4570

'Professor Bruce Cumings' Endorsement'. https://parkyuha.org/archives/5757
} 
with rightist parties, her research challenged the leftist, anti-Japan narrative and was publicized by new-right media: Park was personally interviewed by Jeong Kyu-jae TV.

\section{Counting - and Countering - Low Road's Costs}

The anti-DPRK campaign in USA, and anti-Japan campaign in South Korea, draw on and contribute to larger, illiberal trends in western democracies. An influential, 'low-road' strain of thought frames certain groups as enemies of freedom, and justifies the dissemination of selective and false information and punitive censorship.

Low-road, anti-deliberative practices limit the opportunity and capacity of citizens to discuss the full costs and benefits of government policies. The anti-DPRK campaign's Manichean narrative discourages critical, self-reflection among Americans on how US power is used and abused abroad. US media and policymakers would do well to listen to credible, nonpartisan actors (e.g., faith-based workers, social scientists), whose nuanced accounts suggest that North Korea today is not too different from China of late 1970s, both in its significant human rights violations and real desire to integrate with western countries. Normalization of external ties dramatically increased the liberties of Chinese citizens, and likely will do the same for North Koreans. The US-led sanctions campaign condemns the North Korean people to a closed, stagnant economy, as in Maoist China.

Perhaps even more problematic is the three-decade campaign to frame the Japanese colonial regime's rights violations as equivalent to that of German Nazis', and the current Japanese government as holocaust denialists. Although the most dramatic claims (e.g., forced abductions) lack empirical corroboration, anticolonial leftists promote them with religiouslike fervor and - in South Korea—strictly punish dissenting academics. The ongoing Korean public boycott of products from, and tourism to, Japan has damaged Korean airlines and other businesses more than Japanese, and the trade war shall accelerate if Korean courts start liquidating the seized property of Japanese 'wartime' companies on 4 August 2020. ${ }^{56}$

More fundamentally, the anti-Japan crusade limits Koreans' negative and positive liberties to critically self-reflect on the injustices of their own society before, during, and after colonial era; it leads to ahistorical, fantastical dramas, such as The King: Eternal Monarch (2020), which imagines an alternate universe of a wealthy, never-colonized Korea, governed by a benevolent monarch, allied with peaceful China, and confronting a militarist Japan. South Korea is likely the only advanced (OECD) democracy, whose popular media idealizes the pre-colonial monarchy and portrays modern Japan as more militarist than China.

In US and South Korea, the Manichean, anticommunist and anticolonial narratives are both challenged by a mix of low-road partisans and high-road, principled liberals. Currently, the most maligned and persecuted are the critics of the anticolonial narrative in South Korea, but they also promise the most radical changes to the popular imagination and politics of their country.

Individual liberty is inextricably linked to informed public discourse and prudent policymaking. The crisis in US-North Korea and South Korea-Japan relations partly originates from an illiberal, Manichean politics that overlook complex nuances and possibilities. The remedy is more open, rational public discourse that promotes mutual understanding and genuine justice.

END

\footnotetext{
${ }^{56}$ Kim So-youn and Noh Ji-won, 'S. Korea, Japan set to clash even further as court releases a public notice of ruling', Hankyoreh, 5 June 2020.
} 